\title{
KONTEKSTUALISASI MISI MELALUI TRADISI PUKUL SAPU DI DESA MORELLA
}

\section{Chresty Thessy Tupamahu, Lilis Suryani Hutahaean}

\section{PENDAHULUAN}

Sebagai bangsa yang memiliki keanekaragaman budaya dan adat istiadat dengan masyarakat yang multikultural, bangsa Indonesia terdiri atas masyarakat yang memiliki ciri khas adat dan budaya masing-masing yang beragam. Keanekaragaman itu menjadi sumber kekayaan yang sangat berharga dalam memperkaya kebudayaan nasional. Masyarakat yang dikenal masih menjaga dan melestarikan adat dan kebudayaan asli daerahnya serta mengembangkan ciri-ciri khas hukum adat sering, disebut dengan masyarakat adat. Masyarakat adat merupakan istilah umum yang dipakai di Indonesia yang merujuk pada jenis masyarakat asli Indonesia yang menempati suatu wilayah tertentu. Dapat dipahami juga bahwa masyarakat adat adalah suatu kesatuan manusia yang teratur, menetap di suatu daerah tertentu, mempunyai penguasapenguasa, dan mempunyai kekayaan yang berwujud atupun tidak berwujud, di mana para anggota kesatuan masing-masing mengalami kehidupan dalam masyarakat sebagai hal yang wajar menurut kodrat alam, dan tidak seorang pun di antara para anggota itu mempunyai pikiran atau kecenderungan untuk membubarkan ikatan yang telah tumbuh atau meninggalkannya dalam arti melepaskan diri dari ikatan untuk selama-lamanya. ${ }^{1}$

Berkenaan dengan salah satu aspek dalam masyarakat adat, yaitu memiliki kekayaan, baik berupa kekayaan yang berwujud maupun yang tidak berwujud, di mana kekayaan yang tidak berwujud tersebut salah satunya ialah adanya tradisi adat yang masih ada dan terus dilestarikan dalam suatu kelompok masyarakat. Suatu tradisi yang dilestarikan dalam masyarakat adat, biasanya memiliki tujuan dan fungsi tertentu, di mana masing-masing tradisi yang dilestarikan di suatu masyarakat adat yang satu berbeda dengan tradisi yang dilestarikan di masyarakat adat lainnya. Tidak sedikit masyarakat

\footnotetext{
${ }^{1}$ Tolib Setiady, Intisari Hukum Adat Indonesia dalam Kajian Kepustakaan, (Bandung: Alfabeta, 2008), 77
} 
Indonesia yang masih mempertahankan adat istiadat dan tradisi asli leluhurnya. Tradisi atau adat istiadat yang biasa dilakukan oleh masyarakat sering kita jumpai di berbagai tempat, salah satunya di wilayah Maluku. Ada begitu banyak warisan budaya atau tradisi yang masih terus dilestarikan oleh masyarakat Maluku. Salah satu tradisi yang sampai saat ini masih ada dan terus dilestarikan di Maluku, secara khusus di Desa Morella ialah tradisi Pukul Sapu.

Tradisi Pukul Sapu menjadi salah satu ritual adat yang tergolong ekstrim oleh karena mempertontonkan aksi saling memukul badan atau tubuh berkali-kali dengan batang lidi (dari pohon mayang), hingga menimbulkan luka sayatan, bahkan sampai mengeluarkan darah. Tradisi Pukul Sapu ini biasanya digelar setiap tahun saat perayaan 7 Syawal setelah umat Muslim selesai merayakan Idul Fitri. Tradisi ini pun telah dilakukan dan terus dilestarikan sejak abad 16 atau di masa penjajahan Portugis dan Belanda sampai saat ini di Desa Morella.

\section{ISTILAH TRADISI PUKUL SAPU DAN PROFIL SINGKAT DESA MORELLA}

Pembahasan Bab I ini terdiri dari Istilah Tradisi Pukul Sapu, dan Profil Singkat Desa Morella.

\section{$\underline{\text { Istilah Tradisi Pukul Sapu }}$}

Istilah Pukul Sapu atau Ukuwala Mahiate merupakan ritual yang menggunakan bahan-bahan yang di antaranya, yaitu sapu lidi atau batang lidi (ukuwala), dan minyak kelapa (nyuwalai). ${ }^{2}$ Kata ukuwala terambil dari bahasa Mamala, yang artinya sapu lidi, sedangkan mahiate artinya baku pukul. Jadi, arti dari ukuwala mahiate ialah baku pukul manyapu. ${ }^{3}$ Jika berdasarkan sejarah terbentuknya tradisi Pukul Sapu, maka asal mula penggunaan istilah tradisi Pukul Sapu ialah ketika terjadi atraksi di mana adanya kontak fisik atau saling pukul antara dua kelompok masyarakat menggunakan sapu lidi atau batang lidi tersebut. Dengan adanya saling pukul menggunakan sapu lidi atau batang lidi inilah, maka tradisi yang tergolong unik ini disebut sebagai tradisi Pukul Sapu.

\footnotetext{
${ }^{2}$ Husen Assagaf, Budaya dan Peradaban Islam di Pulau Ambon: Potret Sejarah Pukul Sapu di Negeri Mamala, (Ciputat: Taman Bacaan Masyarakat, 2014), 5

${ }^{3}$ Ibid., 12
} 


\section{$\underline{\text { Profil Singkat Desa Morella }}$}

Negeri Morella berlokasi di sepanjang pesisir pantai Utara Pulau Ambon, dengan batas-batas sebagai berikut: di sebelah Utara berbatasan dengan Desa Liang, di sebelah Selatan berbatasan dengan Desa Mamala, di sebelah Timur berbatasan dengan Desa Waai, dan di sebelah Barat berbatasan dengan Selat Seram. Negeri Morella berada di sepanjang pesisir pantai dengan ketinggian 0-3 meter di atas permukaan laut, secara umum daratan negeri ini berupa pegunungan dan perbukitan, sehingga negeri ini juga sering dijuluki Negeri Seribu Bukit. Secara administratif Negeri Morella adalah salah satu Negeri yang berada dalam wilayah Kecamatan Leihitu, Kabupaten Maluku Tengah, Provinsi Maluku. Jarak Negeri Morella dengan Ibukota Kabupaten kurang lebih $109 \mathrm{~km}$, sedangkan dengan Ibukota Provinsi kurang lebih $35 \mathrm{~km} .{ }^{4}$

\section{HAKIKAT TRADISI PUKUL SAPU}

Pembahasan tentang hakikat tradisi Pukul Sapu, penulis akan menjelaskan tentang Sejarah Tradisi Pukul Sapu di Desa Morella, Pelaksanaan Tradisi Pukul Sapu di Desa Morella, dan Pandangan Masyarakat Morella terhadap Traisi Pukul Sapu.

\section{$\underline{\text { Sejarah Tradisi Pukul Sapu di Desa Morella }}$}

Atraksi Pukul Sapu Lidi telah menjadi suatu tradisi adat di Negeri Morella sejak dahulu, atraksi ini awalnya adalah menjadi permainan anak-anak di Negeri Kapahaha (Morella), jauh sebelum adanya perang melawan VOC Belanda. Sementara itu, awal mula tradisi ini mulai dipentaskan yaitu pada saat acara perpisahan Kapitan dan Malesi setelah ditawan oleh VOC Belanda di Teluk Sawaletu. Perang Kapahaha yang berlangsung selama 9 tahun, dimulai pada tahun 1636 yakni saat pengepungan Kapahaha dan pendirian markas VOC Belanda di Teluk Sawaletu. Perlawanan demi perlawanan dilakukan demi menghadapi kaum penjajah. Korban berjatuhan di kedua belah pihak,

${ }^{4}$ Sumber dari Buku Panduan Acara: Perayaan Pukul Sapu Negeri Hausihu Morella, Tanggal 0708 Oktober 2008. 
hingga saat penangkapan Yata Pori oleh Belanda di Teluk Nandaluhu dan menjadikannya sebagai penunjuk jalan menuju Kapahaha. ${ }^{5}$

Dikisahkan, puncak peperangan ketika penjajah melakukan agresi militernya yaitu selama tujuh hari tujuh malam. Akhirnya pada tanggl 27 Juli 1646 VOC berhasil menyerang dari laut dengan meriam kapal, sedang di sekitar Benteng, pasukan Belanda juga terus melakukan tekanan. Pertempuran berlangsung sengit, dalam detik-detik terakhir ketika benteng tidak mungkin lagi untuk dipertahankan, Telukabessy harus mundur guna menyusun kekuatan kembali melawan Belanda. Sedang pejuang lain banyak gugur. Bahkan Srikandi Kapahaha, Putijah (istri Telukabessy asal Belanda) gugur sebagai pahlawan. ${ }^{6}$

Dengan jatuhnya benteng di Kapahaha, banyak masyarakat dan kapitan ditangkap dan ditawan di Teluk Sawatelu. Beberapa di antaranya diasingkan ke Batavia. Gubernur di Ambon kemudian memerintahkan agar Kapitan Telukabessy segera menghadap di markas VOC untuk bertanggung jawab atas perlawanan dan membebaskan rakyatnya yang ditawan. Jika tidak, maka seluruh rakyat yang ditawan akan dibunuh. Dengan jiwa kekapitanannya, maka pada tanggal 19 Agustus 1646 Telukabessy menghadap Komandan Verheijden. Di hadapan Gubernur Gerard Demmer Telukabessy mengajukan beberapa tuntutan tegas, namun tuntutan tersebut tidak diindahkan oleh Belanda. Hingga pada akhirnya Kapitan Telukabessy digantung pada tanggal 13 September 1646 di Benteng Victoria, Ambonia. ${ }^{7}$

Setelah perlawanan Telukabessy berakhir, maka pada tanggal 27 Oktober 1646 Gubernur Gerard Demmer membebaskan pejuang-pejuang Kapahaha yang telah ditawan selama 3 bulan lamanya. Pembebasan tawanan perang Kapahaha diselingi dengan acara perpisahan, maka pada acara inilah dipentaskan tarian adat yang bernafaskan sejarah dengan nyanyian lagu-lagu kapata sejarah. Turut pula serombongan pemuda Kapahaha mempertunjukkan atraksi Pukul Manyapu. Para Kapitan dan Malesi larut dalam atraksi ini. Lukaluka berdarah dapat mengingatkan perjuangan berdarah pada perang Kapahaha yang telah berlalu. ${ }^{8}$

Setelah selesai acara perpisahan, maka dibuat tiga kelompok yang dipimpin oleh tiga malesi menggunakan tiga Sawat untuk kembali ke daerah asal. Satu Sawat adalah rombongan ke Huamual, Buru dan sekitarnya. Satu

\footnotetext{
${ }^{5}$ Sumber dari Buku Panduan Acara: Perayaan Pukul Sapu Negeri Hausihu Morella ...

${ }^{6}$ Ibid.

${ }^{7}$ Ibid.

${ }^{8}$ Ibid.
} 
Sawat ke Pulau-pulau Lease yaitu Hatuhaha di Haruku; Iha Ulu Palu di Saparua, Hulawano di Nusa Laut; dan satu Sawat menuju Seram, Kaibobu, Tuhulele, Latu, Tambilou dan Manusela. Ada juga malesi-malesi dari luar Maluku yang disebut Suku Mahu, di antaranya tiga orang Karaeng dari Kerajaan Gowa Makassar, Mataram dan lain-lain. Perpisahan sangat berkesan dengan pekikan-pekikan dan cucuran air mata serta sumpah setia dengan satu ikrar untuk menetapkan Atraksi Pukul Manyapu menjadi tradisi adat dan membudaya sepanjang masa. Sejak itulah maka tradisi Pukul Manyapu selalu diadakan di Negeri Morella setiap tanggal 7 Syawal sebagai salah satu media untuk mengenang kembali perjuangan para leluhur di Benteng Kapahaha. ${ }^{9}$

\section{$\underline{\text { Pelaksanaan Tradisi Pukul Sapu di Desa Morella }}$}

Upacara adat yang tergolong ekstrem ini digelar setiap tanggal 7 Syawal menurut perhitungan kalender Hijriah atau kalender Islam, atau pada hari ke tujuh setelah Hari Raya Idul Fitri di Desa Morella. Biasanya, peserta upacara adalah para pemuda di daerah itu, namun bila ada peserta dari daerah lain yang ingin berpartisipasi, bisa mendaftarkan diri kepada panitia tiga hari sebelum upacara dilaksanakan. Sekalipun Pukul Sapu adalah tradisi umat Islam Maluku, namun upacara ini juga dihadiri dan melibatkan umat Kristen, terutama mereka yang memiliki ikatan kekerabatan (pela-gandong) dengan masyarakat Morella, misalnya masyarakat Desa Waai yang mempunyai hubungan kekeluargaan dengan masyarakat Desa Morella. Terkadang peserta upacara ini juga diikuti oleh keturunan Maluku yang sudah menjadi warga negara Belanda. ${ }^{10}$

Sebelum acara puncak Pukul Sapu berlangsung, terlebih dahulu digelar berbagai kegiatan, seperti hadrat (rebana), karnaval budaya, pameran dan festival, balap perahu, penampilan band lokal, dan bahkan penampilan artis ibukota keturunan Maluku. Selain itu, juga ditampilkan aneka tari dari daerah tersebut, seperti tari putri, tari mahina, tari perang, hingga pertunjukan musik yang dibawakan oleh masyarakat dari negeri pela yang beragama Kristen. Sementara itu, meskipun pelaksanaan upacara baru dimulai setelah shalat Ashar (sekitar jam tiga siang), para wisatawan, baik domestik maupun mancanegara, telah berbondong-bondong datang ke desa Morella sejak pagi hari. Bahkan, ada yang tiba di sana satu atau dua hari sebelum upacara dimulai.

\footnotetext{
${ }^{9}$ Sumber dari Buku Panduan Acara: Perayaan Pukul Sapu Negeri Hausihu Morella ...

$10 \mathrm{http} / / / \mathrm{m}$.wisatamelayu.com/id/tour/859-Upacara-Adat-Pukul-Sapu/navgeo. Diakses pada tanggal 05 Mei 2014.
} 
Hal ini dimaksudkan supaya mereka dapat menyaksikan secara langsung tahapan-tahapan persiapan upacara, seperti melihat latihan para peserta upacara, meraut lidi enau, dan sebagainya. Sebelum upacara Pukul Sapu dimulai, para peserta terlebih dahulu dikumpulkan di suatu tempat untuk mendapatkan doa dari para tetua adat. Hal ini dilakukan dengan harapan agar prosesi upacara berjalan dengan lancar dan seluruh peserta diberi keselamatan oleh Allah Swt. ${ }^{11}$

Di Desa Morella, pembukaan upacara ditandai dengan penyulutan obor Kapitan Telukabessy oleh pejabat atau pemuka masyarakat setempat. Selepas acara pembukaan, upacara adat Pukul Sapu pun dimulai dengan diringi tepuk tangan dan sorak-sorai dari para penonton. Para peserta yang hanya menggunakan celana pendek, ikat kepala, dan bertelanjang dada ini dibagi ke dalam dua kelompok. Masing-masing kelompok terdiri dari 20 orang. Kelompok yang pertama menggunakan celana berwarna merah atau hijau, sedangkan kelompok yang kedua menggunakan celana berwarna putih atau kuning. Setiap peserta berdiri berhadap-hadapan dengan peserta dari kelompok lain di tengah arena seukuran lapangan bola kaki. Tiap orang memegang batang lidi pohon enau untuk disabetkan (dipukulkan).

Saat seruling berbunyi kelompok bercelana merah atau hijau dipersilahkan terlebih dahulu untuk memukul kelompok bercelana putih atau kuning. Begitu pun sebaliknya saat seruling dibunyikan lagi, giliran kelompok bercelana putih dan kuning yang menyerang dan memukul kelompok bercelana merah dan hijau. Kelompok yang mendapat giliran untuk memukul, mundur beberapa langkah untuk mengambil posisi atau jarak pukul ke arah lawan. Peserta dari kelompok lawan berdiri sambil mengangkat lidi di atas kepala dan membiarkan bagian tubuhnya untuk disabet lidi. Kedua kelompok tersebut secara bergantian akan menyabetkan lidi enau yang berada di genggaman masing-masing, ke pinggang, dada, perut dan punggung peserta di hadapannya sampai lebam dan berdarah-darah. Untuk mengatur pergantian kelompok yang dicambuk dan kelompok yang menyambuk, para peserta mengikuti aba-aba (bunyi peluit) dari koordinator upacara (wasit) atau mengikuti alunan gendang. Pergantian juga bisa dilakukan bila peserta yang dicambuk telah terdesak hingga mendekati tempat penonton di pinggir lapangan.

Sabetan lidi yang mengenai badan lawan mengeluarkan bunyi cukup keras menyerupai lecutan cambuk. Terkadang tiga batang lidi yang digunakan sudah hancur hanya dalam hitungan dua atau tiga kali sabetan saja. Pukulan

${ }^{11}$ http://m.wisatamelayu.com/id/tour/859-Upacara-Adat-Pukul-Sapu/navgeo. Diakses pada tanggal 05 Mei 2014. 
lidi berkali-kali mengakibatkan guratan merah memanjang sekujur tubuh para pemain. Sebagian besar sampai mengeluarkan darah. Bahkan tidak jarang potongan batangan lidi pun turut tertancap pada kulit dan luka di tubuh para pemain.

Uniknya, meskipun sekujur tubuh peserta upacara memar-memar dan mengeluarkan darah, tidak sedikit pun terlihat atau terdengar erangan dan jeritan kesakitan para pemain akibat dipukul dengan lidi. Mereka malah sebaliknya terlihat ketagihan untuk dipukul berulang kali. Atraksi ini tentunya membuat gemetar dan ngeri pengunjung yang baru pertama kali menyaksikannya. Tidak jarang warga atau wisatawan yang berada paling dekat dengan arena atraksi, harus meringis kesakitan akibat terkena sabetan batang lidi para pemain. Sebagian besar pemain mengaku tidak merasakan sakit di tubuh mereka yang memar dan luka serta mengeluarkan darah akibat sabetan lidi itu. "Sabetan lidi malah menimbulkan rasa gatal-gatal dan membuat kami ketagihan untuk terus dipukul," ujar beberapa pemain. ${ }^{12}$

Di Desa Morella, luka sabetan dan goresan akibat cambukan lidi enau dapat disembuhkan dengan cepat tanpa meninggalkan bekas. Luka-luka akibat cambukan ini diobati dengan ramuan dari daun jarak yang terkenal berkhasiat menyembuhkan luka. ${ }^{13}$ Setelah upacara adat Pukul Sapu usai, hal lain yang menarik dan membuat wisatawan terhibur adalah ketika para penonton berlomba-lomba memperebutkan lidi-lidi enau sisa-sisa dari pementasan upacara adat Pukul Sapu. Hal ini dikarenakan lidi-lidi enau tersebut diyakini dapat membawa keberuntungan. Selain untuk memperoleh keberuntungan, sebagian masyarakat menganggap kedua benda tersebut sekadar kenangkenangan telah menyaksikan upacara adat Pukul Sapu yang dilaksanakan sekali dalam setahun itu. Sedangkan bagi touris yang punya waktu luang, dapat mengikuti Pesta Basudara, yaitu acara syukuran upacara adat Pukul Sapu, yang digelar di Desa Morella pada malam hari setelah upacara adat tersebut berlangsung.

Dalam tradisi ini tidak ada dendam, karena Pukul Sapu merupakan simbol persaudaraan. Para pejuang dari berbagai daerah di Maluku, Gowa (Sulawesi Selatan) dan Mataram (Jawa) pernah bersatu melawan penjajah di sini," tutur Raja Negeri Morella. ${ }^{14}$ Luka-luka di tubuh peserta Pukul Sapu

\footnotetext{
${ }^{12}$ Wawancara Antara Maluku dengan beberapa peserta upacara Pukul Sapu. http://www.antaramaluku.com/berita/24981/atraksi-adat-pukul-sapu-pukau-ribuan-penonton. Diakses pada tanggal 05 Mei 2014.

${ }^{13}$ http://m.wisatamelayu.com/id/tour/859-Upacara-Adat-Pukul-Sapu/navgeo. Diakses pada tanggal 05 Mei 2014.

${ }^{14}$ Wawancara Harian Kompas dengan Abdul Kadir, selaku Raja Negeri Morella.
} 
merupakan simbol untuk mengenang persatuan para pejuang di bawah pimpinan Kapitan Telukabessy. Tradisi Pukul Sapu penuh dengan petuah, yakni untuk saling menjaga persatuan dan persaudaraan.

\section{Pandangan Masyarakat Desa Morella terhadap Tradisi Pukul Sapu}

Secara umum, masyarakat Desa Morella sangat bersemangat untuk terus mengadakan dan melestarikan tradisi Pukul Sapu, karena bagi mereka, tradisi Pukul Sapu merupakan warisan dari para leluhur mereka, sekaligus sebagai upaya untuk terus melestarikan nilai-nilai heroik perjuangan rakyat ketika melawan penjajah. Tradisi Pukul Sapu juga, diharapkan dapat menjadi bagian dari khazanah budaya nasional yang berakar pada sejarah perjuangan Perang Kapahaha, sehingga tradisi ini harus terus dijaga dan dilestarikan. ${ }^{15}$

Masyarakat Desa Morella berharap agar melalui tradisi Pukul Sapu ini, momen untuk terus membina dan meningkatkan persatuan dan kesatuan antar suku, agama, maupun ras, dapat terlaksana melalui terciptanya suasana kekeluargaan dan kebersamaan. Masyarakat Desa Morella pun sangat berharap, dengan terlaksananya tradisi Pukul Sapu ini, hubungan silaturahmi antar anak cucu Kapitan dan Malesi terus dibangun. ${ }^{16}$ Secara khusus, bagi masyarakat di Desa Morella, melalui tradisi Pukul Sapu ini, setiap tetesan darah dari tubuh para pemuda (peserta Pukul Sapu) yang mengalir keluar, jatuh dan meresap ke tanah, dapat mengingatkan mereka untuk berkumpul kembali di tempat tersebut (tanah) suatu saat nanti.

\section{KONTEKSTUALISASI MISI MELALUI TRADISI PUKUL SAPU DI DESA MORELLA}

Alkitab dengan tegas menyatakan bahwa kewajiban mengabarkan Injil atau kabar sukacita adalah tugas dan tanggung jawab dari setiap orang yang telah menerima Kristus menjadi Tuhan dan Juruselamatnya (Mat. 5:13-16, 28:19-20 ; Kis. 1:8, 8:4 ; 2 Kor. 5:20). Setiap orang percaya wajib mengabarkan

http://nasional.kompas.com/read/2008/10/21/21420256/warisan.telukabessy.di.negeri.seribu.bukit. Diakses pada tanggal 05 Mei 2014.

${ }^{15}$ Sumber dari Buku Panduan Acara: Perayaan Pukul Sapu ...

${ }^{16}$ Ibid. 
Injil sesuai kemampuan dan karunia-karunia yang dianugerahkan Roh Kudus kepadanya. ${ }^{17}$ Injil atau Kabar sukacita ini menyangkut berita keselamatan manusia dan dunia seluruhnya. Kabar sukacita ini berkaitan dengan kehidupan manusia, baik secara spiritual maupun material, baik secara fisik maupun nonfisik, baik perorangan mapun kemasyarakatan. ${ }^{18}$ Tugas pemberita Injil juga merupakan usaha untuk memahami atau menafsirkan pesan yang dimaksudkan oleh Roh Kudus melalui teks-teks Alkitab, kemudian menjelaskan atau mengkomunikasikan pesan itu di dalam suatu cara yang berarti dan yang meyakinkan kepada pendengar di dalam konteks dari kebudayaan mereka. ${ }^{19}$ Secara misiologis, hambatan yang akan dihadapi dan dirasakan ketika memberitakan Injil di dalam suatu konteks atau kebudayaan, ialah ketika Injil tersebut diberitakan atau disampaikan, namun konteks dari si penerima maupun konteks dari si pemberita Injil itu berbeda, dan tidak adanya saling memahami konteks masing. ${ }^{20}$ Oleh karena itu, maka si pemberita Injil pun harus memperhatikan konteks, bahkan dapat menjadikan penginjilan tersebut sebagai penginjilan yang kontekstual.

Kontekstualisasi sendiri merupakan konsep usaha untuk memahami konteks kehidupan manusia secara luas dalam dimensi budaya, agama, sosial, ekonomi dan politik yang berhubungan dengan situasi yang menyeluruh, dengan tujuan agar pemberitaan Injil dapat dilakukan dengan baik dan dipahami secara tepat oleh setiap orang yang hidup dalam konteks tersebut. ${ }^{21}$

Menurut Tomatala, ada beberapa model pendekatan kontekstualisasi yang memberikan gambaran umum tentang usaha berteologi dalam konteks, dengan tujuan untuk mengevaluasi sejauh mana pendekatan teologi kontekstualisasi yang Alkitabiah dapat terlaksana. Model-model pendekatan kontekstualisasi tersebut di antaranya: ${ }^{22}$

\footnotetext{
${ }^{17}$ D.W. Ellis, Metode Penginjilan, (Jakarta: Yayasan Komunikasi Bina kasih/OMF, 1999), 7

${ }^{18}$ Fridolin Ukur, “Bersikap Injili dalam Konteks Kebudayaan (Daerah)”, Agama dalam Dialog: Pencerahan, Pendamaian dan Masa Depan: Punjung tulis 60 tahun Prof. Dr. Olaf Herbert Schumann, Kontributor oleh Panitia Penerbitan Buku Kenangan Prof. Dr. Olaf Herbert Schumann, (Jakarta: BPK Gunung Mulia, 1999), 426

${ }^{19}$ David J. Hesselgrave, Communicating Christ Cross-Culturaly: Mengomunikasikan Kristus Secara Lintas-Budaya, (Malang: Literatur SAAT, 2004), 105

${ }^{20}$ Robert P. Borrong, dkk., Berakar di Dalam Dia: 80 tahun Prof. Dr. P.D. Latuihamallo, (Jakarta: BPK Gunung Mulia, 2002), 171

${ }^{21}$ Y. Tomatala, Penginjilan Masa Kini, (Malang: Gandum Mas, 1988), 64

${ }^{22}$ Ibid., 67-69
} 


\section{- Model Akomodasi}

Akomodasi adalah sikap menghargai dan terbuka terhadap kebudayaan asli yang dilakukan dalam sikap, kelakuan dan pendekatan praktis dalam tugas misionaris, baik secara teologi maupun secara ilmiah. Dalam mengkomunikasikan Injil terjadi proses penetrasi, dan dalam penerapannya terdapat pengambilalihan unsur budaya setempat dalam mengekspresikan dan meningkatkan sambutan atas Injil. Model ini memandang kebudayaaan dengan positif bahwa anugerah Allah tidak menghancurkan budaya manusia, tetapi melengkapi dan menyempurnakannya. Contoh sikap akomodasi terdapat dalam Kisah Para Rasul 17:28.

\section{- Model Adaptasi}

Perbedaan model adaptasi dan akomodasi terletak pada cara pendekatannya. Model adaptasi tidak mengasimilasikan unsur budaya dalam mengekspresikan Injil, tetapi menggunakan bentuk dan ide budaya yang dikenal. Tujuan adaptasi ialah menterjemahkan Injil dalam istilah setempat sehingga menjadi relevan dalam situasi budaya tersebut. Contohnya, Yohanes menggunakan ide logos untuk menjelaskan kebenaran penjelmaan atau inkarnasi Yesus Kristus (Yoh. 1), dan Paulus menggunakan konsep rahasia (2 Kor. 3:18).

\section{- Model Prossesio}

Prossesio adalah sikap yang menanggapi kebudayaan secara negatif. Kelompok prossesio melihat kebudayaan sebagai sesuatu yang sudah rusak oleh dosa, dan tidak ada kebaikan yang muncul dari dalamnya. Proses prossesio beroperasi dalam tiga tahap, yaitu dalam sejarah pengilhaman Alkitab dan misi Kristen, Allah menguasai bangsa-bangsa, serta pembangunan jemaat-Nya untuk menguasai seluruh bangsa dan budaya.

\section{- Model Transformasi}

Allah berada di atas budaya, dan melalui budaya itu pula Allah berinteraksi dengan manusia. Jika seseorang diperbarui oleh Allah, maka inti kebudayaannya juga dibarui (2 Korintus 5:17).

\section{- Model Dialektik}

Model ini adalah interaksi dinamis antara teks dengan konteks. Konsep ini didukung oleh perkiraan yang kuat bahwa perubahan pasti ada dalam setiap 
kebudayaan. Untuk setiap kurun waktu, perubahan itu terjadi secara dinamis. Dengan demikian gereja harus menggunakan peran kenabiannya untuk menganalisa, menginterpretasi dan menilai setiap keadaan.

Berdasarkan beberapa model yang telah dipaparkan di atas, maka model yang dapat diadopsi untuk mengkontekstualisasikan Injil melalui tradisi Pukul Sapu ialah model adaptasi. Alasan menggunakan model adaptasi ialah karena dari hasil kajian peneliti terhadap tradisi Pukul Sapu, ada beberapa aspek atau unsur dari tradisi tersebut yang dapat digunakan sebagai sarana untuk mengekspresikan serta menterjemahkan berita Injil. Adapun beberapa aspek atau unsur dari tradisi Pukul Sapu yang dapat digunakan untuk mengekspresikan dan menterjemahkan Injil melalui model adaptasi, ialah:

a) Salah satu pandangan masyarakat Desa Morella ialah dengan adanya tradisi Pukul Sapu, hubungan kekerabatan yang dikenal dengan istilah pelagandong dapat terjalin kembali setelah sekian lama terputus akibat konflik di Maluku. Ketika konflik menyebabkan adanya rasa benci ataupun dendam, namun mereka telah melupakan semuanya dan rindu untuk kembali hidup rukun, saling menghargai, menghormati, serta saling mengasihi satu dengan yang lain. Sejalan dengan pandangan mereka, Firman Tuhan pun mengajarkan demikian, bahwa: Mengasihi sesama manusia (Mat. 22:39), mengasihi musuh (Mat. 5:44), jangan membenci sesama (Im. 19:17), jangan menuntut balas serta jangan menaruh dendam terhadap orang-orang sebangsa (Im. 19:18).

b) Salah satu alasan masyarakat Desa Morella menggelar tradisi Pukul Sapu ini ialah adanya keinginan untuk terus menjaga hubungan silaturahmi antar anak cucu Kapitan dan Malesi. Pandangan ini dapat digunakan juga untuk menterjemahkan Injil. Sejalan dengan pandangan ini, Firman Tuhan juga mengingatkan tentang ajaran hidup rukun dengan satu dengan yang lain, dalam satu kekeluargaan (Maz. 133:1).

c) Pengorbanan Kapitan Tulukasbessy pun dapat digunakan untuk mengekspresikan serta menterjemahkan Injil, yakni melalui penderitaan dan pengorbanan Tuhan Yesus di kayu salib. Jika kapitan Tulukabessy, dengan jiwa kapitannya mau berkorban menyelamatkan nyawa anak buah dan rakyatnya, terlebih Tuhan Yesus yang rela mati untuk menebus dosa-dosa semua umat manusia (Yoh. 10:15-18). 
d) Dalam kisah kematian kapitan Tulukabessy, ia mati digantung oleh Belanda. Sedangkan dalam kisah kematian Tuhan Yesus, Ia harus mati di atas kayu salib (Yoh. 19:19 ; Kis. 13:29 ; Flp. 2:8).

e) Tradisi Pukul Sapu di Desa Morella berawal dari ungkapan perpisahan antar pejuang perang Kapahaha yang pernah bersatu melawan penjajah. Setiap tetesan darah yang mengalir keluar dari tubuh para peserta Pukul Sapu dapat mengingatkan mereka kembali akan perjuangan para leluhur mereka. Dalam mengekspresikan serta menterjemahkan Injil, tradisi Perjamuan Kudus atau mengingat kembali kematian Tuhan Yesus pun dapat menjadi jembatan untuk menceritakan Injil, jika darah dari tubuh peserta Pukul Sapu dapat mengingatkan mereka akan perjuangan para leluhur mereka, maka roti dan anggur yang dalam Perjamuan Kudus terus mengingatkan setiap orang yang percaya akan pengorbanan Tuhan Yesus. Bedanya, jika para leluhur mereka menang atas penjajah, maka Tuhan Yesus menang terhadap kuasa Iblis (Ibr. $2: 14)$.

Mengutip penjelasan dari Ellis mengenai prinsip-prinsip dalam kegiatan pekabaran Injil di suatu desa, maka sangatlah penting untuk memperhatikan:

- Kehidupan masyarakat desa adalah serba keluarga dan merupakan kesatuan "masyarakat kecil". Karena itu, kehadiran pembawa Injil di suatu desa adalah sebagai tamu atau pendatang luar. Pembawa Injil harus berhati-hati, jangan sampai menyinggung perasaan atau melanggar peraturan maupun kebiasaan desa tersebut. Sebelum menyampaikan Injil, pembawa Injil harus terlebih dahulu mempelajari suasana, lingkungan dan pola hidup masyarakat itu.

- Penting sekali bagi pembawa Injil untuk mendekati para pemuka masyarakat dan memperoleh perkenanan dan dukungan mereka.

- Penampilan pembawa Injil (termasuk dalam hal berpakaian dan sikap berbahasa) jangan mencolok, melainkan harus sederhana, sesuai dengan masyarakat desa itu yang mungkin cara pergaulannya berbeda dengan cara pembawa Injil.

- Pembawa Injil harus menyadari bahwa besar kemungkinan tingkat pendidikan dan pengalaman masyarakat desa itu tidak luas, sehingga daya nalar mereka agak sederhana, baik terhadap orang luar maupun terhadap ajaran baru. Tetapi pembawa Injil harus mengingat bahwa dalam hal akali, besar kemungkinan mereka tidak kalah dengan orang yang berpendidikan. 
Pembawa Injil harus bisa menghargai keterampilan dan keahlian dalam bidang mereka, misalnya dalam hal peternakan, pertanian, bahkan mungkin kerajinan tangan.

- Orang yang di desa biasanya pertama-tama mempercayakan dirinya kepada "seseorang" kemudian barulah kepada berita yang dibawa oleh orang tersebut. Karena itu, pembawa Injil harus lebih dahulu menciptakan hubungan persahabatan dengan mereka, dan janganlah terlalu berharap bahwa mereka akan segera menerima Kristus.

- Harus diingat juga bahwa desa adalah semacam dunia yang kecil dengan masyarakat yang jumlahnya sedikit. Dalam dunia yang sedemikian, bisa saja terjadi ketegangan antara masyarakatnya. Karena itu, kehadiran pembawa Injil janganlah untuk memperuncing ketegangan itu, melainkan meredakan dan menghilangkannya.

- Setiap pembawa Injil harus bisa mengikuti teladan Tuhan Yesus, yakni harus menghindar dari soal-soal politik. Yang diberitakan ialah Kerajaan Sorga bukan kerejaan politik. ${ }^{23}$

\section{SIMPULAN}

Mengabarkan Injil ialah upaya orang percaya dalam menyampaikan kabar kasih karunia Allah kepada seseorang, sehingga ia berpaling dari dosadosanya dan percaya kepada Allah melalui Anak-Nya, Yesus Kristus dengan kuasa Roh Kudus. Melihat kondisi di Maluku, dan secara khusus di Desa Morela, maka berita Injil pun haruslah sampai dan mengubah hidup mereka. Saat ini hampir sebagian besar orang Maluku masih belum mendengar tentang Tuhan Yesus dan karya keselamatan-Nya. Karena tradisi Pukul Sapu telah menjadi salah satu tradisi yang sangat populer dan hampir sebagian besar orang Maluku mengetahui tradisi ini, maka upaya menyampaikan Injil melalui tradisi ini dapat dimanfaatkan, dengan harapan ada banyak orang yang mendengar dan menerima kabar keselamatan, secara khusus masyarakat di desa Morella.

Keberhasilan pelayanan lintas budaya atau pelayanan khusus melalui suatu tradisi tidak hanya ditentukan pada pemahaman tentang tradisi tersebut, melainkan juga dibutuhkan pemahaman yang luas akan ilmu kontekstualisasi itu sendiri, sehingga antara tradisi dan strategi atau metode yang akan dipakai dapat rancang atau disiapkan dengan baik agar peluang untuk bisa masuk atau

${ }^{23}$ D.W. Ellis, Metode Penginjilan..., 149-150 
menceritakan Injil melalui tradisi tersebut dapat diterima dan juga dapat dipahami dengan baik.

Berikut adalah rekomendasi penulis bagi Sekolah Tinggi Teologi, dan bagi semua orang percaya.

\section{Bagi Sekolah Tinggi Teologi}

1) Sebagai wadah pendidikan tinggi teologi yang dipakai Tuhan untuk memperlengkapi serta membentuk semua mahasiswa yang ada untuk siap melayani dalam setiap situasi dan kondisi, maka tulisan ini diharapkan dapat meningkatkan pemahaman pentingnya pelayanan lintas budaya, karena ada banyak orang, dalam budaya yang berbeda, yang masih hidup dalam kegelapan. Bukan hanya untuk mereka yang belum pernah sama sekali mendengar tentang Tuhan Yesus, tetapi juga ada banyak orang memperkatakan Kristus sebagai Tuhan, namun dalam hidup mereka, sikap melakukan kehendak Kristus dan Firman-Nya tidak tercermin.

2) Diharapkan semua sekolah tinggi teologi lebih lagi memperlengkapi semua mahasiswa akan pemahaman yang luas tentang pelayanan lintas budaya, khususnya pelayanan kontekstualisasi misi. Karena kenyataan yang ada sebagian mahasiswa teologi yang masih belum memahami, bahkan mendengar model atau metode kontekstualisasi misi tertentu, apalagi melakukannya.

3) Diharapkan agar lebih banyak lagi sekolah tinggi teologi mengadakan seminar-seminar pelayanan lintas budaya yang dapat memperlengkapi mahasiswa dan dosennya.

\section{Bagi Semua Orang Percaya}

1) Tuhan telah mengerjakan karya keselamatan yang kekal. Untuk menyelamatkan manusia atas hukuman dosa, Yesus Kristus harus mati di kayu salib. Oleh karena itu, semua orang percaya harus benar-benar merasa prihatin dan memikirkan keadaan manusia yang saat ini hidup dalam kegelapan, tersesat, bahkan hidup tanpa Tuhan Yesus.

2) Berkaitan dengan tradisi Pukul Sapu, maka pihak pertama yang harusnya terbeban dan punya kerinduan untuk memberitakan Injil melalui tradisi ini ialah semua orang yang berasal dari Maluku, khususnya yang sungguh punya hati untuk melihat jiwa-jiwa yang tersesat ini. Dari segi pemahaman akan budaya di Maluku secara umum dapat menjadi modal penting, kemudian apabila harus menggunakan tradisi ini sebagai sarana kontekstualisasi Injil, maka pihak yang menjadi sasaran penginjilan tidak 
akan meragukan apa yang akan disampaikan, oleh karena ada rasa percaya terhadap sang pemberita Injil, yang dinilai berasal juga dari daerah yang sama, sehingga pasti mengerti akan budaya di daerah tersebut.

\section{DAFTAR PUSTAKA}

2003 Alkitab Terjemahan Baru. Jakarta: Lembaga Alkitab Indonesia

Assagaf, Husein

2014 Budaya dan Peradaban Islam di Pulau Ambon: Potret Sejarah

Pukul Sapu di Negeri Mamala. Ciputat: Taman Bacaan

Masyarakat

Borrong, Robert P., dkk.,

2002 Berakar di Dalam Dia dan Dibangun di Atas Dia: 80 tahun

Prof. Dr. P.D. Latuihamallo. Jakarta: BPK Gunung Mulia

Ellis, D.W.

1999 Metode Penginjilan. Jakarta: Yayasan Komunikasi Bina kasih/OMF

Hesselgrave, David J.

2004 Communicating Christ Cross-Culturaly: Mengomunikasikan

Kristus Secara Lintas-Budaya. Malang: Literatur SAAT

Setiady, Tolib

2008 Intisari Hukum Adat Indonesia dalam Kajian Kepustakaan.

Bandung: Alfabeta

Tomatala, Y.

1988 Penginjilan Masa Kini. Malang: Gandum Mas 
Ukur, Fridolin

1999 “Bersikap Injili dalam Konteks Kebudayaan (Daerah)”, Agama dalam Dialog: Pencerahan, Pendamaian dan Masa Depan: Punjung tulis 60 tahun Prof. Dr. Olaf Herbert Schumann, Kontributor oleh Panitia Penerbitan Buku Kenangan Prof. Dr. Olaf Herbert Schumann. Jakarta: BPK Gunung Mulia

\section{Sumber Lainnya:}

- Buku Panduan Acara: Perayaan Pukul Sapu Negeri Hausihu Morella, Tanggal 07-08 Oktober 2008.

\section{Sumber dari Internet:}

- $\quad$ http://m.wisatamelayu.com/id/tour/859-Upacara-Adat-Pukul$\underline{\text { Sapu/navgeo }}$

- $\quad$ http://nasional.kompas.com/read/2008/10/21/21420256/warisan.telukab essy.di.negeri.seribu.bukit

- $\quad$ http://www.antaramaluku.com/berita/24981/atraksi-adat-pukul-sapupukau-ribuan-penonton 